\title{
TANGGUNGJAWAB NEGARA TERHADAP KEBAKARAN HUTAN DI INDONESIA DITINJAU DARI PERSPEKTIF HUKUM INTERNASIONAL
}

\section{THE STATE'S RESPONSIBILITY FOR FOREST FIRES IN INDONESIA IN TERMS OF AN INTERNATIONAL LEGAL PERSPECTIVE}

\author{
Sutia Fadli' ${ }^{1}$ T. Nazaruddin ${ }^{2}$, Mukhlis ${ }^{3}$ \\ ${ }^{1}$ Mahasiswa Program Studi Magister Hukum Universitas Malikussaleh \\ ${ }^{2,3}$ Dosen Program Studi Magister Hukum Universitas Malikussaleh \\ Email: sutiafadli@gmail.com
}

\begin{abstract}
This thesis examines the state's responsibility for forest fires in Indonesia in terms of an international legal perspective. Forest fires in Indonesia are getting more and more severe. Losses suffered by other countries as a result of forest fires make the concept of state accountability to the public for injuries to other countries questioned again. This research then formulates two legal issues namely the State Responsibility for Forest Fires in the Perspective of International Law and the Completion of International Law on Forest Fires in Indonesia. This study uses two approaches, namely the Statutory Approach and the Conceptual Approach. Based on the results of the author's analysis, it can be concluded that the responsibility for forest fires in Indonesia has been set in various laws and regulations, also when viewed from an international legal perspective, in the Draft Articles on State Responsibility adopted by the International Law Commission. The responsibility of the state is regulated in the articles of the Draft Articles on State Responsibility. Settlement of international legal disputes can be resolved through courts in the form of International Arbitration, which is a dispute resolution that is done by presenting disputes to certain people and the dispute must be agreed by both parties to the dispute, then the settlement of disputes through an international court (International Court) This international court functions to adjudicate every country whether member or non-member of the disputed UN. Then there are also out-of-court settlements in the form of negotiations, mediations, good services, conciliations, investigations, discoveries, and regional settlements.
\end{abstract}

Keywords: Forest fire, state responsibility, international law

\section{Intisari}

Tesis ini mengkaji tentang tanggungjawab negara terhadap kebakaran hutan di Indonesia ditinjau dari perspektif hukum Internasional. Kebakaran hutan di Indonesia semakin kian parah, Kerugian yang dialami negara lain sebagai akibat 
kebakaran hutan membuat konsep pertanggungjawaban negara yang masyarakat adanya injury bagi negara lain kembali dipertanyakan. Penelitian ini kemudian merumuskan dua isu hukum yaitu Tanggungjawaban Negara terhadap kebakaran hutan dalam Perspektif Hukum Internasional dan Penyelesaian Hukum Internasional terhadap kebakaran hutan di Indonesia. Penelitian ini menggunakan dua pendekatan, yaitu Pendekatan Peraturan PerundangUndangan (statute approach) dan Pendekatan Konsep (conceptual approach). Berdasarkan hasil analisis penulis, maka dapat diperoleh kesimpulan bahwa tanggungjawab terhadap kebakaran hutan di Indonesia telah di atur dalam berbagai peratutan perundang-undangan, juga jika dilihat dari perspektif hukum internasional, dalam Draft Articles on State Responsibility yang di adopsi oleh Internationl Law Commision. Tanggungjawab negara diatur dalam pasal-pasal Draft Articles on State Responsibility. Penyelesaian sengketa hukum internasional dapat diselesaikan melalui pengadilan berupa Arbitrase Internasional yaitu suatu penyelesaian sengketa yang dilakukan dengan cara menyajikan sengketa kepada aorang-orang tertentu dan sengketa tersebut harus persetujuan kedua belah pihak yang bersengketa, kemudian penyelesaian sengketa melalui pengadilan internasional (Mahkamah Internasional) mahkamah internasional ini berfungsi mengadili setiap negara-negara baik anggota atau bukan anggota PBB yang bersengketa. Kemudian ada juga penyelesaian diluar pengadilan yang berupa negosisasi, mediasi, jasa baik, konsiliasi, penyelidikan, penemuan, dan penyelesaian regional.

Kata Kunci: Kebakaran hutan, tanggungjawab negara, hukum internasional.

\section{A. Latar Belakang Masalah}

Perlindungan hukum yang harus dipenuhi oleh setiap negara terhadap warga negaranya adalah menjamin setiap warga negara untuk terpenuhinya hakatas lingkungan yang baik. Di Indonesia secara khusus telah diatur dalam Undang-Undang Dasar Negara Republik Indonesia Tahun 1945, sebagaimana tercantum dalam Pasal 28H Ayat 1 Undang-Undang Dasar Negara Republik Indonesia Tahun 1945 yang menyatakan, "Setiap orang berhak hidup sejahtera lahir dan batin, bertempat tinggal, dan mendapatkan lingkungan hidup yang baik dan sehat serta berhak memperoleh pelayanan kesehatan". ${ }^{1}$ Maka untuk itu lingkungan hidup yang baik dan sehat merupakan hak asasi dan hak konstitusional bagi setiap warga negara.

Indonesia sebagai negara yang menjunjung tinggi hak asasi manusia juga telah meratifikasi deklarasi umum hak asasi manusi (DUHAM), UndangUndang Nomor 39 tahun 1998 tentang Hak Asasi Manusia, dimana dalam undang-undang tersebut juga memasukkan hak atas lingkungan, sabagaimana disebutkan dalam Pasal 9 ayat (3) menegaskan: "setiap orang berhak atas lingkungan hidup yang baik dan sehat". 2 Upaya ratifikasi ini kemudian menyakatan bahwa Indonesia adalah salah satu negara yang mengakui dan menghargai hak asasi manusia yang berlaku secara universal dan bersifat

1 Undang-Undang Dasar Negara Republik Indonesia 1945.

2 Undang-Undang Nomor 39 Tahun 1998 tentang Hak Asasi Manusia 
mengikat, artinya tidak hanya berlaku pada warga negara dalam negeri saja melainkan juga wajib melindungi hak katas lingkungan warga negara lain. Dengan demikian Indonesia menjadi negara, pemerintah, dan seluruh pemangku kepentingan berkewajiban untuk melakukan perlindungan dan pengelolaan lingkungan hidup dalam pelaksanaan pembangunan berkelanjutan agar lingkungan hidup Indonesia dapat tetap menjadi sumber dan penunjang hidup bagi rakyat Indonesia serta makhluk hidup lain.

Namun perkembangannya, pencemaran lingkungan yang berakibat pada rusaknya lingkunan terus terjadi seiring dengan perkembangan zaman serta motif dan jenisnya yang beragam. Kerusakan lingkungan hidup semakin hari kian parah. Kondisi tersebut secara langsung telah mengancam kehidupan manusia. Tingkat kerusakan alam pun meningkatkan risiko bencana alam. Penyebab terjadinya kerusakan alam dapat disebabkan oleh dua faktor yaitu akibat peristiwa alam dan akibat ulah manusia. Salah satunya adalah kerusakan hutan akibat ulah sengaja manusia demi dapat melakukan eksploitasi sumber daya alam dengan cara membakar hutan.

Kebakaran hutan dan lahan yang terjadi di Indonesia semakin mendapatkan perhatian internasional dan harus segera ditindaklanjuti. Kebakaran hutan dan lahan tersebut tidak hanya menimbulkan kerugian pada negara asal tempat terjadinya kebakaran, namun juga kerugian pada negara lain berupa pencemaran asap lintas batas Negara contohnya di Malaysia dan Singapura. Hal tersebut menimbulkan pertangungjawaban negara (Indonesia) karena kejadian pencemaran asap lintas batas yang menyebabkan terganggunya lingkungan negara lain merupakan tindakan yang bertentangan dengan prinsipprinsip hukum internasional.

Kebakaran hutan merupakan sebuah peristiwa yang seharusnya menjadi tanggung jawab sebuah negara terhadap negara dan rakyatnya. Kebakaran hutan ini terkadang menimbulkan polemic diplomatic antara Indonesia, Singapura, dan Malaysia karena telah terjadi pencemaran udara (asap) lintas batas yang disebabkan oleh kebakaran hutan di Indonesia yang sering terjadi di pulau Kalimantan dan Sumatra khususnya di Riau yang menyebar sampai kekawasan negara tetangga, yaitu Malaysia dan Singapura.

Menurut data Kementerian Lingkungan Hidup dan Kehutanan Republik Indonesia (KLHK RI) kebakaran hutan dan lahan di Indonesia dari tahun 2014 sampai dengan tahun 2019 mencapai luasan 3. 776. 009, 81 Ha yaitu pada Tahun 2014 seluas 44.411,36 Ha, tahun 2015 seluas 2.611.411,44 Ha, tahun 2016 seluas 438.363,19 Ha, tahun 2017 seluas 165.483,92 Ha, tahun 2018 seluas 510.564,21 Ha, dan pada tahun 2019 seluas 5.775,69 Ha. ${ }^{3}$ Jika merujuk pada data KLHK RI maka dapat dilihat bahwa dari tahun 2014 sampai dengan tahun 2019 kebakaran hutan dan lahan terbesar terjadi pada tahun 2015. Jumlah kebakaran hutan dan lahan tersebut tersebar di 34 kabupaten kota, sebagaimana dijelaskan pada table berikut ini.

3 Data ini diperoleh dari Kementerian Lingkungan Hidup dan Kehutanan Republik Indonesia (KLHK RI) melalui website http://sipongi.menlhk.go.id/hotspot/luas_kebakaran, yang diakses pada tanggal 2 April 2019.

Suloh: Jurnal Fakultas Hukum Universitas Malikussaleh, Vol. 7, No. 2, April 2019, pp. 48-76 
Luas Kebakaran Hutan Dan Lahan (Ha) Per Provinsi Di Indonesia Tahun 2014-2019

\begin{tabular}{|c|c|c|c|c|c|c|c|}
\hline \multirow{2}{*}{ No. } & \multirow{2}{*}{ PROVINSI } & \multicolumn{6}{|c|}{ Luas Hutan Yang Terbaka Setiap Tahunnya } \\
\hline & & 2014 & 2015 & 2016 & 2017 & 2018 & 2019 \\
\hline 1 & Aceh & 155,66 & 913,27 & $9.158,45$ & $3.865,16$ & $1.284,70$ & 81,86 \\
\hline 2 & Bali & 30,00 & 373,46 & - & 370,80 & 206,54 & - \\
\hline 3 & BangkaBelitung & - & $19.770,81$ & - & - & $2.055,67$ & - \\
\hline 4 & Banten & 2,00 & 250,02 & - & - & - & - \\
\hline 5 & Bengkulu & 5,25 & 931,76 & $1.000,39$ & 131,04 & 8,82 & - \\
\hline 6 & DKI Jakarta & - & - & - & - & - & - \\
\hline 7 & Gorontalo & - & $5.225,89$ & 737,91 & - & 158,65 & - \\
\hline 8 & Jambi & $3.470,61$ & $115.634,34$ & $8.281,25$ & 109,17 & $1.390,90$ & - \\
\hline 9 & Jawa Barat & 552,69 & $2.886,03$ & - & 648,11 & $4.104,51$ & - \\
\hline 10 & Jawa Tengah & 159,76 & $2.471,70$ & - & $6.028,48$ & 331,67 & - \\
\hline 11 & Jawa Timur & $4.975,32$ & $7.966,79$ & - & $5.116,43$ & $7.279,76$ & - \\
\hline 12 & KalimantanBarat & $3.556,10$ & $93.515,80$ & $9.174,19$ & $7.467,33$ & $68.311,06$ & 221,02 \\
\hline 13 & KalimantanSelatan & 341,00 & $196.516,77$ & $2.331,96$ & $8.290,34$ & $98.637,99$ & - \\
\hline 14 & KalimantanTengah & $4.022,85$ & $583.833,44$ & $6.148,42$ & $1.743,82$ & $41.521,31$ & 8,45 \\
\hline 15 & KalimantanTimur & 325,19 & $69.352,96$ & $43.136,78$ & 676,38 & $26.605,57$ & $2.807,2$ \\
\hline 16 & KalimantanUtara & - & $14.506,20$ & $2.107,21$ & 82,22 & 625,82 & - \\
\hline 17 & KepulauanRiau & - & - & 67,36 & 19,61 & 320,96 & 232,91 \\
\hline 18 & Lampung & 22,80 & $71.326,49$ & $3.201,24$ & $6.177,79$ & $14.963,87$ & - \\
\hline 19 & Maluku & 179,83 & $43.281,45$ & $7.834,54$ & $3.918,12$ & $14.131,33$ & - \\
\hline 20 & Maluku Utara & 6,50 & $13.261,10$ & 103,11 & 31,10 & 69,54 & 33,41 \\
\hline 21 & NusaTenggara Barat & $3.977,55$ & $2.565,71$ & 706,07 & $33.120,81$ & $14.352,26$ & - \\
\hline 22 & NusaTenggaraTimur & 980,87 & $85.430,86$ & $8.968,09$ & $38.326,09$ & $55.207,64$ & - \\
\hline 23 & Papua & 300,00 & $350.005,30$ & $186.571,60$ & $28.767,38$ & $87.676,88$ & - \\
\hline 24 & Papua Barat & - & $7.964,41$ & 542,09 & $1.156,03$ & 120,63 & - \\
\hline 25 & Riau & $6.301,10$ & $183.808,59$ & $85.219,51$ & $6.866,09$ & $37.220,74$ & $1.994,26$ \\
\hline 26 & Sulawesi Barat & - & $4.989,38$ & $4.133,98$ & 188,13 & 978,38 & - \\
\hline
\end{tabular}

Suloh: Jurnal Fakultas Hukum Universitas Malikussaleh, Vol. 7, No. 2, April 2019, pp. 48-76 


\begin{tabular}{|l|l|c|c|c|c|c|c|}
\hline 27 & SulawesiSelatan & 483,10 & $10.074,32$ & 438,40 & $1.035,51$ & $1.741,27$ & 396,57 \\
\hline 28 & SulawesiTengah & 70,73 & $31.679,88$ & $11.744,40$ & $1.310,19$ & $3.890,95$ & - \\
\hline 29 & SulawesiTenggara & $2.410,86$ & $31.763,54$ & 72,42 & $3.313,68$ & $8.121,35$ & - \\
\hline 30 & Sulawesi Utara & 236,06 & $4.861,31$ & $2.240,47$ & 103,04 & 125,07 & - \\
\hline 31 & SumateraBarat & 120,50 & $3.940,14$ & $2.629,82$ & $2.227,43$ & $2.421,90$ & - \\
\hline 32 & SumateraSelatan & $8.504,86$ & $646.298,80$ & $8.784,91$ & $3.625,66$ & $13.019,68$ & - \\
\hline 33 & SumateraUtara & $3.219,90$ & $6.010,92$ & $33.028,62$ & 767,98 & $3.678,79$ & - \\
\hline 34 & Yogyakarta & 0,27 & - & - & - & - & - \\
\hline & TOTAL & $\mathbf{4 4 . 4 1 1 , 3 6}$ & $\mathbf{2 . 6 1 1 . 4 1 1 , 4 4}$ & $\mathbf{4 3 8 . 3 6 3 , 1 9}$ & $\mathbf{1 6 5 . 4 8 3 , 9 2}$ & $\mathbf{5 1 0 . 5 6 4 , 2 1}$ & $\mathbf{5 . 7 7 5 , 6 9}$ \\
\hline
\end{tabular}

Sumber:Data ini diperoleh dari Kementerian Lingkungan Hidup dan Kehutanan Republik Indonesia (KLHK RI)

Kerusakan lingkungan akibat kebakaran hutan ini kemudian tidak hanya berdampak pada suatu wilayah di Indonesia akan tetapi seluruh Indonesia, bahkan negara-negara lain juga ikut terkena dampak lingkungan, salah satunya dampak akibat kebakaran hutan yang menyebabkan negara-negara tetangga mengalami dampak lingkungan.Akan tetapi, hutan yang seharusnya diurus dan dimanfaatkan secara optimal dengan memperhatikan aspek kelestarian telah mengalami degradasi dan deforestasi yang cukup mencengangkan bagi dunia Internasional. Indonesia merupakan satu negara yang masuk dalam daftar rekor dunia Guiness yang dirilis oleh Greenpeace sebagai negara yang mempunyai tingkat laju deforestasi tahunan tercepat di dunia. Sebanyak 72 persen dari hutan asli Indonesia telah musnah dengan 1.8 juta hektar hutan dihancurkan per tahun antara tahun 2000 hingga 2005, sebuah tingkat kehancuran hutan sebesar 2\% setiap tahunnya atau $51 \mathrm{~km} 2$ per hari atau dalam satu jam luas hutan Indonesia yang hancur setara dengan 300 lapangan sepakbola ${ }^{4}$

Disaat upaya untuk menjajaki, memulihkan dan mempertahankan kondisi hutan melalui mekanisme jasa hutan sebagai penyerap karbon dilakukan, sebuah prestasi Internasional tercatat kembali bagi bangsa Indonesia karena hutan yang dimilikinya. Kebakaran hutan di Indonesia telah menempatkan Indonesia sebagai negara yang termasuk dalam deretan negara penyumbang emisi $\mathrm{CO}_{2}$ terbesar di dunia. Masalah kebakaran hutan telah menjadi isu nasional yang patut mendapat perhatian serius dari pemerintah mengingat dampaknya yang sangat merugikan bagi kehidupan manusia. ${ }^{5}$

Didalam Prinsip Hukum Internasional disebutkan Bahwa setiap negara tetap memiliki kedaulatan terhadap wilayahnya. ${ }^{6}$ Negara dapat menurunkan peraturan hukum wajib untuk wilayahnya, memiliki kekuatan eksekutif (adiminstratif, kebijakan), dan pengadilannya adalah satu-satunya yang berwenang untuk mengadili. Permasalahan kebakaran hutan ini menjadi masalah

${ }^{4}$ Saniya Ilma Arifa., Kajian Dan Analisis Kasus Kejadian Kebakaran Hutan Di Indonesia, 2015 , hlm 5.

${ }^{5}$ Ibid., hlm 6

6 Widodo, Hukum Internasional Publik, Aswaja Pressindo, Yogyakarta, 2017, hlm. 39 
internasional karena kasus ini menimbulkan pencemaran di negara-negara tetangga (transboundary pollution) sehingga mereka mengajukan protes terhadap Indonesia atas terjadinya masalah ini dan meminta Negara Indonesia bertanggungjawab atas dampak yang ditimbulkan oleh kebakaran hutan tersebut.

Hukum internasional mewajibkan setiap negara untuk mengambil langkahlangkah yang diperlukan untuk mengontrol dan menangani sumber pencemaran global yang serius atau sumber perusakan lintas batas yang ada dalam jurisdiksi mereka. Dalam kasus Trial Smelter prinsip itu telah dipakai, dimana dewan arbitrase telah memutuskan bahwa Canadian Smelter harus memberikan ganti rugi kepada Amerika Serikat atas pencemaran yang telah ditimbulkannya. Dewan juga menyatakan prinsip "Sic Utere Tuo Alineun Non Laedas" menegaskan bahwa: No states has the right to use or permit the use of its territory in such a manner as to cause injury by fumes in or to the territory of another and that measures of control were necessary" (Tidak ada negara bagian yang memiliki hak untuk menggunakan atau mengizinkan penggunaan wilayahnya sedemikian rupa sehingga menyebabkan cedera oleh asap di timbulkan ke wilayah lain dan bahwa tindakan pengendalian diperlukan). ${ }^{7}$

Pasal 2 huruf (a) Undang-Undang Nomor 32 Tahun 2009 tentang Pengelolaan dan Perlindungan Lingkungan Hidup, ${ }^{8}$ disebutkan bahwa Perlindungan dan pengelolaan lingkungan hidup dilaksanakan berdasarkan asas tanggung jawab Negara.Namun didalam praktiknya Indonesia gagal dalam mengelola lingkungan hidup, sehingga terjadinya kebakaran lahan yang diakibatkan oleh ulah tangan manusia.

Menurut subjeknya, perjanjian internasional dibedakan menjadi 2, yaitu perjanjian bilateral dan perjanjian multilateral. ${ }^{9}$

1. Perjanjian bilateral, adalah suatu bentuk perjanjian yang dibuat atau diadakan oleh dua negara.

2. Perjanjian multilateral, adalah suatu bentuk perjanjian yang diadakan oleh lebih dari dua negara.

Kebakaran hutan yang terjadi di Indonesia jika dilihat dari segi subjeknya tergolong kedalam perjanjian multilateral, dalam pertanggungjawaban tersebut terjadinya benturan antara prinsip Internasional dengan perjanjian Internasional, sehingga dalam perjanjian Internasional Negara Indonesia tidak dapat dituntut sebagai pelaku atas kebakaran hutan, akan tetapi ganti kerugian terhadap kebakaran hutan tersebut yang dapat di tuntut. Apabila suatu negara melanggar perjanjian internasional (traktat) maka berlaku asas setiap pelanggaran suatu perjanjian menimbulkan kewajiban untuk mengganti kerugian. ${ }^{10}$

\footnotetext{
7 Wikipedia, http://www.negarahukum.com/hukum/prinsip-prinsip-hukumlingkungan internasional.html (Diakses Pada Tanggal 31 Agustus 2017)

${ }^{8}$ Pemerintah Republik Indonesia Undang-Undang Nomor 32 Tahun 2009 tentang Perlindungan dan Pengelolaan Lingkungan Hidup.

9 Wikipedia, Perjanjian-Internasional, Diakses pada tanggal 3 Oktober 2018,

10 Widodo.,Hukum Internasional Publik, Aswaja Pressindo, Yokyakarta, 2017, hlm 108
}

Suloh: Jurnal Fakultas Hukum Universitas Malikussaleh, Vol. 7, No. 2, April 2019, pp. 48-76 
Sementara dalam prinsip Internasional ${ }^{11}$ disebutkan dalam asas Pacta Sunt Servanda "Setiap perjanjian yang telah dibuat harus ditaati oleh pihak-pihak yang mengadakannya, sehingga kebakaran hutan di Indonesia merupakan tanggungjawab Negara, namun bukan hanya Indonesia yang bertanggung jawab akan tetapi negara lain juga turut serta bertanggungjawab, artinya dalam pertanggungjawaban terhadap kebakaran hutan diperlukannya hukum internasional dalam memperkuat hukum positif di Indonesia.

Dalam tata hukum internasional, ketentuan berkenaan dengan masalah pertanggungjawaban negara ini memang belum ada yang pasti. International Law Commision (ILC), salah satu organ PBB yang bertugas untuk melakukan perumusan dan pembahasan ketentuan dan hukum internasional sampai saat ini masih berusaha merumuskan dan membahas draft tentang ketentuan tanggung jawab negara.

Meskipun hasil kerjanya masih dalam bentuk draft, tetapi aktivitas ILC dalam mempersiapkan dan melakukan perkembangan hukum internasional khususnya mengenai tanggung jawab negara yang dilakukan oleh para ahli hukum terkemuka yang mewakili kebudayaan-kebudayaan terpenting di dunia yang mempunyai nilai tinggi yang tergabung di dalam Panitia Hukum Internasional (ILC), dapat digunakan sebagai sumber tambahan hukum internasional.

Timbulnya tanggung jawab negara atas lingkungan didasarkan pada adanya tindakan-tindakan atau kegiatan-kegiatan yang dilakukan yang berada di wilayah suatu negara atau di bawah pengawasan negara tersebut yang membawa akibat yang merugikan terhadap lingkungan tanpa mengenal batas negara.

Hukum lingkungan internasional mengatur bahwa setiap negara mempunyai hak yang sama untuk mendapatkan lingkungan yang baik dan sehat bagi warga negaranya. Pasal 5 butir 1 Undang- Undang Nomor 23 tahun 1997 tentang Ketentuan-Ketentuan Pokok Pengelolaan Lingkungan Hidup (UUPLH) menyebutkan bahwa setiap orang berhak atas lingkungan yang baik dan sehat. Demikian pula Deklarasi Universal PBB mengenai Hak-Hak Asasi Manusia 10 Desember 1948 menegaskan bahwa setiap orang berhak atas standar kehidupan yang memadai untuk kesehatan dan kesejahteraan dirinya. ${ }^{12}$

Tanggung jawab negara terhadap akibat-akibat dari tindakannya terhadap negara lain dan hak-hak negara terhadap lingkungan ditegaskan pula dalam Konferensi PBB tentang Lingkungan Hidup di Stockholm tahun 1972. Prinsip 21 Deklarasi Stockholm (Resolusi MU No. 2992 (XXVII)) 15 Desember 1972) menyatakan bahwa setiap negara mempunyai hak berdaulat untuk mengeksploitasi kekayaan alamnya dan bertanggung jawab agar kegiatan eksploitasi yang dilakukan di dalam wilayah atau di bawah pengawasannya tersebut tidak menyebabkan kerugian atau kerusakan terhadap negara lain.

11 Nirmala Nurdin, prinsip-prisip-umum-hukum-internasional, diakse pada tanggal 3 Oktober 2018

12 The Universal Declaration of Human Rights : A Guide for Journalist. Terjemahan : Hendriati Trianita, Deklarasi Universal Hak Asasi Manusia : Panduan bagi Jurnalis, Lembaga Studi Pers dan Pembangunan (LSPP), cet. 2, Jakarta, 2000, hlm. 36

Suloh: Jurnal Fakultas Hukum Universitas Malikussaleh, Vol. 7, No. 2, April 2019, pp. 48-76 
Rumusan yang sama ditetapkan dalam Pasal 194 Konvensi Hukum Laut 1982, ${ }^{13}$ yaitu bahwa Negara harus mengambil tindakan yang perlu untuk menjamin agar kegiatan-kegiatan yang berada di bawah yurisdiksinya atau di bawah pengawasannya dilakukan dengan cara sedemikian rupa sehingga tidak mencemari wilayah negara lain.

Sedangkan ketentuan Prinsip 22 Deklarasi Stockholm berkaitan dengan masalah tanggung jawab dan kompensasi bagi para korban pencemaran akibat kebakaran hutan dan kerusakan lingkungan lainnya yang disebabkan oleh kegiatan di dalam wilayah yurisdiksi atau di bawah pengawasan suatu negara. Hal serupa dikemukakan Komar Kantaatmadja, yakni bahwa perbuatan yang menyebabkan terjadinya kerugian menimbulkan kewajiban untuk memenuhi ganti rugi. Berdasarkan dari uraian tersebut di atas, ada beberapa permasalahan yang menjadi objek kajian dalam penelitian ini yaitu bagaimanakah pertanggungjawaban Negara terhadap kebakaran hutan dalam perspektif hukum Internasional dan bagaimanakah penyelesaian sengketa hukum Internasional terhadap kebakaran hutan di Indonesia.

\section{B. Metode Penelitian}

Penelitian merupakan sarana yang digunakan oleh manusia untuk memperkuat, membina serta mengembangkan suatu ilmu pengetahuan dengan tujuan untuk kepentingan masyarakat luas. ${ }^{14}$ Penelitian ini menggunakan metode penelitian yuridis normatif. Penelitian yuridis normatif (hukum normatif) adalah metode penelitian hokum yang dilakukan dengan meneliti bahan pustaka atau data sekunder belaka ${ }^{15}$ dengan membahas doktrin-doktrin atau asas-asas dalam ilmu hukum (studi dogmaticldoktrinal research) dan sering juga disebut sebagai penelitian yang bersifat teoritis. Penelitian dilakukan terhadap asas-asas hukum, sitematika hukum dan taraf singkronisasi hukum. ${ }^{16}$ Pendekatan ini mengacu pada norma-norma hukum yang terdapat dalam peraturan per undang-undangan dan putusan-putusan pengadilan serta norma hukum yang terdapat di dalam masyarakat. ${ }^{17}$ Pendekatan yang dilakukan dengan cara meneliti terlebih dahulu asas-asas dan peraturan per undang-undangan yang relevan dengan permasalahan yang diteliti dengan mengkaji hukum dari aspek normatif terkait dengan surat edaran. ${ }^{18}$

Penelitian ini menggunakan pendekatan perundang-undangan (statute approach) dan pendekatan konseptual (conceptual approach). ${ }^{19}$

a) Pendekatan perundang-undangan (statute approach)

13 UN Doc. A/CONF.62/122, "Documents of the UN conference On the Law of the Sea" diakses dari www.search.un.org pada tanggal 22 Mei 2019

14 Soerjono Soekanto, Pengantar Penelitian Hukum, UI Press, Jakarta, 2008, hlm. 3.

15 Soerjono Soekanto \& Sri Mamudji, Op. Cit., hlm. 13-14.

16 Zainuddin Ali, Metode Penelitian Hukum, Cet. 5, Sinar Grafika, Jakarta, 2014, hlm. 24-

27.

17 Ibid., hlm. 105.

18 Soerjono Soekanto, Op. Cit, hlm. 11.

19 Peter Mahmud, Penelitian Hukum, cet. 2. Jakarta: kencana, 2008, hlm. 29.

Suloh: Jurnal Fakultas Hukum Universitas Malikussaleh, Vol. 7, No. 2, April 2019, pp. 48-76 
Pendekatan perundang-undangan (statute approach) merupakan suatu pendekatan yang tidak dapat melepaskan diri dari ketentuan per undangundangan. ${ }^{20}$ Pendekatan yang dilakukan terhadap berbagai aturan hukum yang berkaitan dengan objek penelitian. ${ }^{21}$ Aturan hukum yang dimaksud adalah aturan hukum baik yang telah disahkan dan berlaku pada tataran nasional maupun aturan hukum yang bersifat internasional, yang pada intinya aturan hukum yang akan digunakan menjadi bahan hukum dalam penelitian ini adalah segala aturan hukum yang berkitan dengan pertanggungjawaban negara terhadap kebakaran hutan di Indonesia ditinjau dari perspektif hukum internasional.

b) Pendekatan konseptual (conceptual approach)

Pendekatan konseptual (conceptual approach) dilakukan ketika belum atau tidak ada aturan hukum yang mengatur mengenai permasalahan yang dihadapi. ${ }^{22}$ Pendekatan konseptual digunakan untuk memahami konsepkonsep yang berkaitan dengan kewenangan pengujian surat edaran dalam kerangka sistem hukum Indonesia. Ditemukannya konsep yang jelas maka diharapkan penormaan dalam aturan hukum ke depan tidak lagi terjadi pemahaman yang kabur dan bersifat ambigu. ${ }^{23}$

Sumber data yang digunakan dalam penelitian ini yaitu data sekunder yaitu data yang diperoleh melalui bahan pustaka. ${ }^{24}$ Pelaksanaannya dilakukan dengan mengumpulkan dan mempelajari peraturan perundang-undangan, buku-buku, jurnal, dokumen resmi, dan hasil penelitian para pakar yang berkaitan dengan pengujian surat edaran dalam sistem hukum Indonesia. Metode pengumpulan data yang diperlukan dalam penulisan ini adalah menggunakan metode penelitian kepustakaan (library research), mempelajari buku-buku literatur, majalah-majalah, bulletin dan jurnal, dokumen resmi serta mempelajari peraturan perundang-undangan yang ada hubungannya dengan masalah yang akan dibahas. Data sekunder itu sendiri dapat diperoleh dengan menelusuri beberapa bahan hukum, yaitu sebagai berikut:

a) Bahan hukum primer merupakan bahan hukum yang mengikat serta memiliki daya otoritas yang tinggi. Data dari bahan hukum primer akan diperoleh melalui pengkajian peraturan perundang-undangan maupun putusan pengadilan. ${ }^{25}$

b) Bahan hukum sekunder merupakan bahan hukum yang memberi penjelasan terhadap bahan hukum primer yang berbentuk dokumen tidak resmi. Data tersebut diperoleh dari hasil-hasil penelitian, hasil penelitian

${ }^{20}$ Peter Mahmud Marzuki, Penelitian Hukum: Edisi Revisi, Cet. 8, Kencana Prenada Media Group, Jakarta, 2013, hlm.136.

21 Johnny Ibrahim, Teori, Metode dan Penelitian Hukum Normatif,Bayumedia Publising,Malang, 2007, hlm. 300.

22 Peter Mahmud Marzuki, Op. Cit., hlm. 177.

${ }^{23}$ Johnny Ibrahim, Op. Cit., hlm. 300.

24 Zainuddin Ali, Op. Cit., hlm. 23.

${ }^{25}$ Peter Mahmud Marzuki, Op. Cit., hlm. 182-187.

Suloh: Jurnal Fakultas Hukum Universitas Malikussaleh, Vol. 7, No. 2, April 2019, pp. 48-76 
dari para pakar, skripsi, tesis, disertasi hukum, jurnal hukum, artikel hukum, komentar atas putusan pengadilan yang berkaitan dengan pengujian terhadap surat edaran, serta buku-buku ruang lingkup hukum tata negara dan hukum administrasi negara. ${ }^{26}$

c) Bahan hukum tersier ${ }^{27}$ yaitu bahan hukum yang memberi petunjuk maupun penjelasan terhadap bahan hukum primer dan bahan hukum sekunder yang diperoleh dari kamus bahasa Indonesia maupun kamus hukum.

Analisis data merupakan suatu kegiatan yang dilakukan oleh penulis dalam hal menentukan isi dan makna aturan hukum yang dijadikan pegangan dalam menyelesaikan permasalahan yang dikaji. ${ }^{28}$ Setelah dilakukan pengumpulan data, selanjutnya diseleksi, diklasifikasi, dan disusun dalam bentuk narasi. Pengolahan data yang telah dilakukan dengan menggunakan metode berfikir deduktif, kemudian disatukan dalam satu bentuk karya ilmiah. Metode berpikir deduktif yaitu cara berpikir dalam penarikan kesimpulan yang ditarik dari sesuatu yang sifatnya umum yang sudah dibuktikan kebenarannya dan kesimpulan itu ditujukan untuk sesuatu yang sifatnya khusus. $^{29}$ Sebagai prosedur penelitian yang menghasilkan data deskriptif berupa pengumpulan tertulis maupun lisan penelitian kepustakaan dan penelitian lapangan dianalisis secara kualitatif.

\section{Hasil Penelitian dan Pembahasan}

1. Tanggungjawab Negara Terhadap Kebakaran Hutan di Indonesia dalam Perspektif Hukum Internasional

a. Kondisi Obyektif Kebakaran Hutan Di Indonesia

Dapat dikatakan bahwa hutan Indonesia menjadi paru-paru dunia karena Indonesia memiliki hutan sebesar 53\% dari luas total didunia, dimana jenis hutannya adalah hutan tropis yang dimiliki Indonesia sepanjang hamparan kepulauannya, khususnya di Sumatera, Kalimantan dan Irian Jaya. Hutan dari hasil hutan Indonesia merupakan pemasok utama kayu tropis dunia. Dengan tercatat besar dan banyaknya jumlah hutan di Indonesia serta hasil dari hutan itu khususnya kayu yang menjadi hasil utama mengakibatkan banyaknya terjadi penebangan liar dan kebakaran hutan. Persoalan lingkungan hidup yang sering sekali dibahas dalam beberapa tahun belakangan ini adalah persoalan lapisan ozon yang semakin menipis dan perubahan iklim yang semakin tidak menentu. Permasalahan perusakan hutan yang khususnya terjadi di Riau akibatnya dirasakan oleh masyarakat sekitar hutan dan masyarakat sekitar wilayah Sumatera dan juga meliputi aspek lepas batas negara yang mengakibatkan kerugian bagi masyarakat warga negara tetangga Indonesia. Kebakaran hutan di

${ }^{26}$ Ibid., hlm. 195-196.

27 Zainuddin Ali, Op. Cit., hlm. 23-24.

28 Zainuddin Ali, Op. Cit., hlm. 107.

29 Sedarmayanti dan Syarifudin Hidayat, Metodologi Penelitian, Mandar Maju, Bandung, 2002, hlm. 23.

Suloh: Jurnal Fakultas Hukum Universitas Malikussaleh, Vol. 7, No. 2, April 2019, pp. 48-76 
Indonesia juga mengakibatkan pencemaran udara di beberapa negara, khususnya negara Malaysia dan Singapura.

Permasalahan kebakaran hutan di Indonesia ini menjadi masalah internasional karena kasus ini menimbulkan pencemaran di negara tetangga (transboundary pollution) sehingga Malaysia dan Singapura mengajukan protes terhadap Indonesia atas terjadinya masalah ini. Malaysia dan Singapura mendesak Indonesia untuk menyelesaikan masalah ini karena kebakaran hutan ini bukan merupakan kejadian yang pertama bagi mereka.

Protes Malaysia dan Singapura ini berlandaskan pada kabut asap tersebut telah mengganggu kehidupan mereka seperti terjadinya gangguan kesehatan masyarakat karena kabut asap yang bersifat racun sehingga terjadinya Infeksi Saluran Pernafasan Akut (ISPA), asma juga kematian, perekonomian yang tidak stabil serta pariwisata mereka. Efek lain dari kabut asap juga dapat meningkatkan kecelakaan lalu lintas baik darat, laut dan udara karena jarak pandang yang sangat pendek.

Ketidakmampuan Indonesia dalam menyelesaikan masalah kebakaran hutan ini bukan berarti bahwa Indonesia merupakan negara yang pasif dalam melindungi lingkungan hidup. Dampak yang terjadi tersebut dapat menjadi dasar untuk meminta pertanggungjawaban negara terhadap negara yang telah melakukan tindakan yang merugikan negara lain. Dalam hal ini kasus kebakaran hutan di Indonesia telah mengakibatkan dampak negatif terhadap negara-negara tetangga (Malaysia Singapura) yang memberikan reaksi-reaksi terhadap negara Indonesia. Kebakaran hutan yang sudah sering terjadi di Indonesia dan menjadi masalah yang telah lama dimiliki Indonesia, dimana Indonesia memiliki hutan hujan tropis yang luas. Permasalahan lingkungan sebenarnya tidak ada mengenal batas wilayah negara maupun wilayah administratif. Dampak kebakaran hutan berupa pencemaran udara yang tidak hanya dirasakan Indonesia saja tetapi sudah sering sekali menyebabkan pencemaran asap lintas batas ke wilayah negara-negara tetangga seperti Malaysia-Singapura. Hal ini adalah masalah serius yang memerlukan penanganan dan tindakan soal penyelesaian yang secepatnya serta dibutuhkan peran aktif dari Indonesia serta harmonisasi hukum antara Indonesia dan Malaysia-Singapura agar terciptanya kerjasama yang baik dalam rangka pencegahan dan pengendalian pencemaran udara lintas batas.

2. Tanggungjawab Negara Terhadap Kebakaran Hutan Di Indonesia Dalam
Perspektif Hukum Internasional
Negara sebagai dasar utama terbentuknya suatu aturan hukum sudah melakukan banyak hal demi terciptanya keadilan dalam mencegah kebakaran hutan di Indonesia, negara Indonesia sudah mengeluarkan aturan-aturan hukum dalam menjaga, melindungi dan mencegah terjadinya kebakaran hutan di Indonesia mulai dari Undang-Undang Dasar 1945 pasal 28H, Undang-Undang Nomor 32 Tahun 2009 tentang lingkungan hidup, Undang-undang Nomor 41 Tahun 1999 tentang Kehutanan, Peraturan Pemerintah No. 45 Tahun 2004 tentang Perlindungan Hutan, Peraturan Menteri KehutananNo. 12 Tahun 2009 tentang Pengendalian Kebakaran Hutan, ini merupakan suatu bentuk 
tanggungjawab Negara dalam mencegah terjadinya kebakaran hutan di Indonesia.

Indonesia juga membuktikan keseriusannya dengan merancang Peraturan Pemerintah tahun 2014 tentang pencegahan kebakaran hutan dan lahan dengan tujuan yaitu Prosedur Operasi Standar ini dimaksudkan untuk menyatukan upaya-upaya lintas kementrian dan Lembaga terkait, Pemda dan Pelaku usaha, Masyarakat serta Pemangku Kepentingan lainnya dalam melakukan pencegahan kebakaran hutan dan lahan secara terpadu, efektif dan efisien, dengan tujuan agar dapat digunakan sebagai pedoman nasional dalam melakukan tindakan penecegahan kebakaran hutan di Indonesia secara tepat tanpa ragu dan menjamin semua upaya dan kegiatan dapat dilakukan secara terkoordinasi dan terintegrasi dengan baik. Sedangkan sasarannya (output) adalah tercegahnya bencana kebakaran hutan dimasa yang akan datang, dan hasil yang diharapkan (outcome)adalah terkelolanya hutan dan lahan berwawasan lingkungan.

Setiap negara pada dasarnya memiliki hak dan kewajibanyang sama dalam hal tanggungjawab negara terlebih dalam prinsip-prinsip hukum internasional yakni semua negara memiliki hak dan kewajiabn yang sama terhadap perlindungan dan menjaga lingkungan dalam memanfaatkan sumber daya alam negaranya masing-masing, dalam prinsip hukum internasional menjelaskan bahwa setiap negara memiliki hak berdaulat atas semua sumber daya yang ada dan bertanggungjawab atas semua tindakan yang dilakukan serta memastikan bahwa tindakan yang diambil dalam pengelolaan sumber daya yang ada tidak menyebabkan kerusakan lingkungan dan membahayakan kesehatan manusia dari negara lain atau diluar batas yurisdiksinya.

Bentuk-bentuk pertanggungjawaban negara diatur dalam Draft Articles on State Responsibility yang diadopsi oleh Komisi Hukum Internasional atau disebut dengan Internasional Law Commision(ILC). Meskipun draft ILC tersebut tidak mengikat sebagai sutau instrumen hukum Internasional karena belum ditetapkan sebagai sebuah produk hukum. Namun demikian, kekuatan mengikat Draft ILC tidak dilihat dari bentuknya sebagai instrumen, melainkan dari isinya. Draft ILC dapat digunakan sebagai sumber tambahan dan mengikat sebagai hukum kebiasaan Internasional ganti rugi atau reparation diatur dalam Pasal 31.

1. The responsible State is Under on obligation to make full reparation for the injury caused by the international wrongful act. (Negara yang bertanggungjawab berkewajiban untuk memberikan reparasi penuh untuk cedera yang disebabkan oleh tindakan yang salah secara Internasional.

2. Injury includes any damage, whether material or moral, caused by the internationally wrongful act of a State.(cedera termasuk kerusakan, apakah materi atau moral yang disebabkan olehtindakan yang salah secara Internasional).

Namun jika dilihat dari Prinsip Internasional, bahwa semua negara memiliki hak dan kewajiban yang sama atas perlindungan dalam pemanfaatan sumber daya alam negaranya masing-masing serta bertanggung jawab atas 
segala tindakan yang dilakukan yang merugikan negara lain diluar batas yurisdiksinya.

Persetujuan Asean Agreement on Transboundary Haze Polution(AATHP) terdiri atas 32 (tiga puluh dua) Pasal dan 1 (satu) lampiran. Materi pokok Persetujuan AATHP antara lain mengatur mengenai: ${ }^{30}$ pemantauan, penilaian, pencegahan, kesiapsiagaan, tanggap darurat nasional, kerja sama teknis dan penelitian ilmiah terkait dengan pengendalian kebakaran lahan dan/atau hutan termasuk pemadaman kebakaran.

Luas hutan alam asli Indonesia menyusut dengan kecepatan yang sangat mengkhawatirkan. Hingga saat ini, Indonesia telah kehilangan hutan aslinya sebesar72 persen. ${ }^{31}$ Penebangan hutan Indonesia yang tidak terkendali selama puluhan tahun dan menyebabkan terjadinya penyusutan hutan tropis secara besar-besaran. Laju kerusakan hutan periode 1985-1997 tercatat 1,6 jutahektar per tahun, sedangkan pada periode 1997-2000 menjadi 3,8 juta hektar pertahun. Ini menjadikan Indonesia merupakan salah satu tempat dengan tingkat kerusakan hutan tertinggi di dunia. Di Indonesia berdasarkan hasil penafsiran citralandsat tahun 2000 terdapat 101,73 juta hektar hutan dan lahan rusak, diantaranya seluas 59,62 juta hektar berada dalam kawasan hutan. ${ }^{32}$

Saat ini kebakaran hutan telah menjadi perhatian internasional sebagai isu lingkungan dan ekonomi. Kebakaran dianggap sebagai ancaman potensial bagipembangunan berkelanjutan karena dampaknya secara langsung pada ekosistem,kontribusi emisi karbon serta bagi keanekaragaman hayati. Propinsi Riau yang letaknya berdekatan dengan Malaysia dan Singapura menjadi sumber transboundaryhaze pollution bagi kedua negara tersebut. Permasalahan kebakaran hutan ini menjadi masalah internasional karena kasus ini menimbulkan pencemaran di negara-negara tetangga (transboundary pollution) sehingga mereka mengajukan protes terhadap Indonesia atas terjadinya masalah ini.

Sebagaimana diketahui bahwa kebakaran hutan tidak hanya dipandang sebagai masalah internal secara nasional sutau negara. Namun yang harus dipahami bahwa kebakaran hutan yang berdampak kepada negara lain, terutama akibat asap yang ditumbulkan berdampak pada lingkungan hidup yaitu kualitas udara negara lain dapat diminta pertanggung-jawaban berdasarkan mekanisme hukum lingkungan internasional.

Hutan sebagai salah satu penentu penyangga kehidupan dan sumber kesejahteraan rakyat yang semakin menurun keadaannya, oleh sebab itu eksistensinya harus dijaga secara terus-menerus, agar tetap abadi dan ditangani dengan budi pekerti yang luhur, berkeadilan, berwibawa, transparan dan

30 Gloria Yuris, Tanggung Jawab Negara Atas Kasus Pencemaran Udara Akibat Kebakaran Hutan Yang Terjadi Di Wilayah Negara Anggota Asean Berdasarkan Asean Agreement On Transbounday Haze Pollution, E-Jurnal, Vol 3. 2015

31 "Documents of the UN conference On the Law of the Sea" diakses dari www.search.un.org

32 Data Diperoleh dari Badan Planologi Dephut Kementerian Lingkungan Hidup dan Kehutanan Republik Indonesia.

Suloh: Jurnal Fakultas Hukum Universitas Malikussaleh, Vol. 7, No. 2, April 2019, pp. 48-76 
profesional serta bertanggung jawab. Penanganan dan pengelolaan hutan yang berkesinambungan dan berpikiran global, harus menyerap aspirasi dan partisipasi masyarakat yang berdasarkan norma hokum yang tertinggi di Indonesia yaitu Pancasila, maupun berdasarkan hukum internasional yang telah disepakati bersama-sama antar negara. Maka apabila terjadi kerusakan terhadap hutan seperti terjadinya kebakaran, penebangan liar dan kerusakan lainnya yang menimbulkan dampak yang kurang baik dalam hidup manusia menjadi masalah yang begitu berat untuk dirasakan oleh Indonesia khususnya pada Provinsi Riau maupun negara tetangga Indonesia yang terdekat seperti Malaysia dan Singapura dan beberapa negara lain yang terkena dampak sesuai dengan arah dan kecepatan mata angin.

Undang-Undang Nomor 41 Tahun 1999 tentang Kehutanan, Pasal 1 ayat (1) Kehutanan adalah sistem pengurusan yang bersangkut paut dengan hutan,kawasan hutan dan hasil hutan yang diselenggarakan secara terpadu. Pasal 2 ayat (2) Hutan adalah suatu kesatuan ekosistem berupa hamparan lahan berisi sumber daya alam hayati yang didominasi pepohonan dalam persekutuan alam lingkungannya, yang satu dengan yang lainnya tidak dapat dipisahkan.Berdasarkan pengertian tersebut, kawasan seperti ini terdapat di wilayah-wilayah yang luas di dunia dan berfungsi sebagai penampung karbon dioksida, habitat hewan,modulator arus hidrologika serta pelestari tanah dan merupakan salah satu aspek biosfer bumi yang paling penting.

Masalah lingkungan akibat kebakaran hutan tidak dapat dilepaskan dari dampak yang ditimbulkan yang langsung berdampak pada kehidupan manusia sehari-hari baik didalam negeri maupun dampak terhadap negara lain. Setelah sekian lama tidak mendapatkan tempat yang memadai untuk diperhatikan, akhirakhir ini masalah lingkungan pun mencuat ke permukaan tanpa dapat dihindari lagi, bahkan telah terjadi hubungan yang diciptakan an tara isu lingkungan dengan masalah perdagangan, dalam hal ini perdagangan intemasional. Untuk itu nampaknya perlu diketahui secara luas prinsip-prinsip dasar yang ada dalam hukum lingkungan intemasional.

Lingkungan hidup adalah adalah kesatuan ruang dengan semua benda, daya, keadaan dan mahluk hidup, termasuk manusia dan perilakunya yang mempengaruhi alam itu sendiri, kelangsungan perikehidupan dan kesejahteraan manusia serta makhluk hidup lain. Perlunya pelestarian fungsi lingkungan hidup yang merupakan rangkaian upaya untuk memelihara kelangsungan daya dukung dan daya tampung lingkungan hidup agar tidak terjadinya ketidakseimbangan yang dapat menyebabkan pencemaran baik secara sengaja oleh orang-orang yang memiliki kepentingan pribadi maupun tidak sengaja karena berkurangnya daya dukung alam, serta pencemaran yang terjadi baik di air maupun terkhususnya pencemaran di udara. Pencemaran lingkungan hidup adalah masuk atau dimasukkannya makhluk hidup, zat, energi, dan/atau komponen lain kedalam lingkungan hidup oleh kegiatan manusia sehingga melampaui mutu lingkungan hidup yang telah ditetapkan. Pencemaran lingkungan yang terjadi merupakan peristiwa masuk tau dimasukkannya makhluk hidup, zat, energi 
dan/atau komponen lain ke dalam lingkungan hidup oleh kegiatan manusia sehingga melampaui baku mutu lingkungan hidup yang telah ditetapkan.

Kriteria baku kerusakan lingkungan hidup adalah ukuran batas perubahan sidat fisik, kimia, dan/atau hayati lingkungan hidup yang dapat ditenggang oleh lingkungan hidup untuk dapat tetap melestarikan fungsinya. Sementara itu, yang dimaksud dengan polutan adalah bahan pencemar lingkungan, dapat berupa bahan kimia, debu, panas, suara, radiasi dan mikroorganisme. Tingkat pencemaran saat ini terasa semakin memperihatinkan. Kondisi lingkungan seperti yang sudah tidak terjaga lagi dan hal ini sangat mengancam keberadaan makhluk di permukaan bumi.

Pencemaran Udara Lintas Batas dapat didefinikan sebagai polusi yang berasal dari suatu negara tetap, dengan menyeberangi perbatasan melalui jalur udara yangdapat menyebabkan kerusakan lingkungan di negara lain. Dampak dari pencemaran udara ini yang berupa kabut asap tidak hanya dirasakan oleh masyarakat Indonesiasaja, namun hingga negara-negara tetangga, khususnya Malaysia dan Singapura.

Sebagai permasalahan Internasional yang sudah lama terjadi, pencemaran lintas batas yang biasa juga disebutkan sebagai Transfrontier Pollution dapat dijabarkan sebagaiberikut:"Pollution of which the physical is wholly or in part situated within the territory of one state and which has deleterious effects in the territory of another state" (Pencemar fisik yang seluruhnya atau sebagian terletak dalam wilayah suatu negara dan yang memiliki efek merusak di wilayah negara lain).

Permasalahan kabut asap yang ditimbulkan dari kebakaran hutan yang terjadi di Indonesia yang menyebar hingga ke negara tetangga, mengakibat pengajuan protesterhadap Indonesia atas terjadinya permasalahan ini. Protes Malaysia dan Singapura ini berdasarkan pada alasan bahwa kabut asap yang sampai ke negara merekamenyebabkan terjadinya gangguan terhadap kesehatan masyarakat. Kabut asap ini menyebabkan Infeksi Saluran Pernafasan Atas (ISPA), batuk, radang dang gangguanparu-paru. Protes yang disampaikan kedua negara ini terhadap Pemerintah Indonesia yang dinilai tidak serius mengatasi kebakaran hutan yang mengakibatkan kabut asappembawa penyakit itu, karena lambatnya penanganan pemerintah dimata Internasional.

Malaysia dan Singapura mendesak agar Pemerintah Indonesia segera mengambil langkah cepat untuk menyelesaikan masalah ini. Namun Indonesia tidak langsung menyetujui permintaan kedua negara tersebut. Pemerintah Indonesia sudah menyampaikan secara resmi permintaan maaf kepada Malaysia dan Singapura yang telah disampaikan langsung oleh Presiden Republik Indonesia yaitu Bapak Susilo Bambang Yudhoyono, akan tetapi kedua negara ini belum dapat menerima permintaan maaf ini dengan baik dan puas.

Pertangungjawaban negara atas kasus kebakaran hutan diatur dalam pasal 3 AATHP mengenai Prinsip-prinsip dan pasal 4 mengenai Kewajiban Umum,namun sangat disayangkan penjelasan mengenai pasal tersebut dirasa sangat kurang, hal ini terlihat dari isi dari AATHP yang tidak memuat sanksi bagi setiap negara yang melanggar ketentuan internasional tersebut, namun 
dalam pelaksanaannya setiap negara tentu tetap bisa menuntut hak nya di depan hukum internasional manakala negara nya merasa telah dirugikan oleh fihak lain

Dalam kasus Transboundary Haze Pollution, negara yang dirugikan dapat saja menggugat Pemerintah Indonesia karena menurut sejumlah konvensi internasional yang juga telah diratifikasi oleh Indonesia, dalam Piagam Stockholm 1972 (pasal 22 dan 23) serta ASEAN Agreement on the Conservation of Nature and Natural Resources 1985, di mana Indonesia telah meratifikasinya, yang memuat ketentuan bahwa negara boleh saja mengeksploitasi sumber daya alam mereka, tetapi berkewajiban untuk memastikan bahwa aktivitas tersebut tidak menimbulkan kerusakan di wilayah negara lain (state responsibility), hal ini pun berlaku sama terhadap negara-negara lain anggota ASEAN. Bentuk dan Mekanisme Pertanggungjawaban Negara Berdasarkan AATHP (Asean Agreement on Transboundary Haze Polution).

Bentuk dan mekanisme dari pertanggungjawaban negara tidak dicantumkan dalam AATHP maka, untuk menjelaskan permasalahan ini peneliti merujuk pada salah satu sumber hukum internasoinal yakni Draft Articles on State Responsibility yang diadopsi oleh International Law Commision.

Bentuk-bentuk pertanggungjawaban negara diatur dalam pasal-pasal Draft Articles on State Responsibility. Ganti rugi atau reparation diatur dalam pasal 31, sedangkan bentuk-bentuk ganti rugi dapat berupa :

1) Restitution (pasal 35): Kewajiban mengembalikan keadaan yang dirugikan seperti semula.

2) Compensation (pasal 36): Kewajiban ganti rugi berupa materi atau uang.

3) Satisfaction (pasal 37): Permintaan maaf resmi.

Indonesia memenuhi pertanggungjawabannya berdasarkan pasal 37 ILC yaitu permintaan maaf secara resmi dan negosiasi atau perundingan. Tanggungjawab Internasonal terhadap kebakaran hutan di Indonesia sudah diatur dalam ILC (Internasional Law Commision) yang merupakan salah satu organ PBB yang bertugas untuk perumusan dan pembahasan ketentuan hukum internasional, yang hingga saat ini masih berusaha merumuskan dan membahas draft tentang ketentuan tanggung jawab negara.

Menurut hukum internasional, pertanggungjawaban negara timbul dalam hal negara yang bersangkutan merugikan negara lain, dan dibatasi hanya terhadap perbuatan yang melanggar Hukum Internasional. apabila kemudian terbukti adanya pelanggaran tersebut, maka diperlukan adanya upaya pemulihan yang dapat berupa satisfaction, misalnya permohonanan ma'af secara resmi, ataupun berwujud pecuniary reparation, misalnya dengan pemberian ganti rugi material. ${ }^{33}$

Persoalan-peroalan yang terkait dalam krisis lingkungan hidup salah satunya kebakaran hutan ini telah dianalisis secara seksama sejak dua puluh tahun lalu oleh Majelis Umum Perserikatan Bangsa-Bangsa dalam Laporan tentang Persoalan-persoalan Lingkungan Hidup Manusia, Tanggal 26 Mei 1969 (Dokumen W/4667), yang dipersiapkan dalam kaitan penyelenggaraan

33 J.G Starke., Hukum Internasional 2, Sinar Grafika, Jakarta, hlm. 46 
Konferensi Stockholm Juni 1972 tentang Lingkungan Hidup Manusia, sesuai dengan Resolusi Majelis Umum Perserikatan Bangsa-Bangsa mengesahkan Laporan, menyerahkan kepada Skretaris Jenderal tanggungjawab secara keseluruhan untuk mengatur dan mempersiapkan konferensi dan membentuk Komite Persiapan.

Laporan tersebut mengidentifikasi tiga penyebab utama yang bertanggungjawab atas memburuknya kondisi lingkungan, yaitu pesatnya pertumbuhan penduduk, mwningkatnya urbanisasi, berkembangnya dan di hasilkannya teknologi baru, yang menyebabkanmeningkatnya tuntutan akan ruang, pangan dan sumber-sumber daya alam. ${ }^{34}$

Dalam prinsip 21 dan 22 Deklarasi lingkungan hidup manusia, dinyatakan tiga prinsip internasional: ${ }^{35}$

1. Negara-negara memiliki hak berdaulat untuk mengeksploitasi sumber daya yang mereka miliki dengan kebijaksanaan-kebijaksanaan bidang lingkungan mereka;

2. Negara-negara bertanggungjawab untuk menjamin bahwa aktifitasaktivitas yang berlangsung di dalam yurisdiksi atau kontrol mereka tidak menimbulkan kerugian terhadap lingkungan negara-negara lain, atau kawasan-kawana diluar batas-batas yurisdiksi nasional;

3. Negara-negara berkewajiban untuk bekerja sama guna mengembangkan lebih lanjut hukum internasional mengenai tanggungjawab dan ganti rugi terhadap korban-korban pencemaran dan kerusakan lingkungan lain diluar yuridiksi nasional.

Prinsip 21 deklarasi Stockholm yang menyatakan hal yang sama,dan hak seperti ini dilindungi oleh hak mengajukan gugatan. Hak-hak tersebut juga dilengkapi dengan hak-hak perlakuan yang sama kepada negara-negara yang tercemar walaupun hak-hak tersebut memiliki batas. Adapun tanggungjawab sipil memiliki penyelesaian untuk masalah di atas dimana protes anatara negara nantinya tidak akan diperlukan. Tanggungjawab sipil juga menerapkan prinsip ipolluter pays dengan baik. Tetapi penerapan tanggungjawab ini tidak akan jalan tanpa adanya kerjasama internasional.

Ketentuan hukum internasional yang mengatur masalah tanggungjawab dan hak-hak negara hingga kini belum ada yang mapan dan terus mengalami perkembangan sesuai dengan perkembangan zaman, maka PBB melalui ILC harus segera merumuskan aturan-aturan yang terkait dengan masalah hak-hak negara khususnya yang berhubungan dengan tanggungjawab negara atas kebakaran hutan. Akan lebih baik apabila Mahkamah Internasional tidak hanya berorientasi pada prinsip ganti rugi dalam kaitannya dengan lingkungan. Mlainkan selalu diimbangi dengan kewajiba-kewajiban lain seperti kewajiban bantuan teknis, kewajiban untuk ikut serta dalam mengatasi dampak dan kewajiban untuk mencegah serta menghentikan dampak selanjutnya.

\footnotetext{
34 J.G. Starke, Pengantar Hukum Internasional, Cetaka Kesepuluh, Sinar Grafika, Jakarta 2010, hlm. 536-537

${ }^{35}$ Ibid., hlm. 545-546
}

Suloh: Jurnal Fakultas Hukum Universitas Malikussaleh, Vol. 7, No. 2, April 2019, pp. 48-76 
Kasus kebakaran hutan di Indonesia yang merugikan negara malaysi dan Singapuran sebenarnya dapat membuat mereka menuntut kerugian materiil dan pembebanan biaya kepada Indonesia untu melakukan rehabilitasi lingkungan, namun Malaysia dan Singapura hanya mengajukan protes melalui jalur diplomasi. Perundingan-perundingan dapat diadakan dalambentuk pembicaraan langsung antara Negara-negara yang terlibat yang biasanya dilakukan menterimenteri luar negeri, duta besar atau wakil-wakil yang ditugaskan. Indonesia sebagai pihak yang bertanggungjawab atas kebakaran hutan harus menyelesaikan kasus kebakaran hutan yang sering terjadi dalam wilayah Indonesia ini terlebih dahulu agar untuk kedepannya kasus ini tidak akan berlanjut ke Mahkamah Internasional.

Untuk itu perlu diadakan kerjasama yang mendalam antara negara-negara tetangga dengan Indonesia. Kerjasama multilater atau regional lebih baik dipersiapkan mulai dari sekarang untuk penanganan khusus di lapangan, dimana dalam hal ini negara yang bersangkutan bersama-sama mengawasi hutan yang ada di Indonesia walaupun kenyataannya hutan itu merupakan hutan Indonesia, tetapi berdampak baik juga beagi negara-negara tetangga seperti Malaysia dan Singapura.

Maka oleh karenanya negara-negara yang dekat dengan indoneisa juga harus sama-sama bertanggungjawab atas kebakaran hutan di Indonesia karena hutan yang luas di Indonesia memeberikan kesejukan bagi negara seperti Malaysia dan Singapura, untuk itu tanggungjawab bersama dalam mencegah danmengawasi terjadinya kebakaran hutan di Indonesia sangat diperlukan agar terciptanya kualitas hutan yang baik dan kebakaran hutan tidak terulang-ulang kembali.

Pada tahun 2010 Menteri Luar Negeri Singapura, George Yeo telah menghubungi Menteri Luar Negeri Indonesia, Marty Natalegawa, untuk mengungkapkan keprihatinannya atas Kabut asap, dan menyampaikan kesiapannya memberi informasi bahwa poluttant standards index (PSI) atas indeks pengukur tingkat pencemaran udara akibat kebakaran hutan yang telah melebihi 100 dan kasus maslaah pernafasan termasuk asma meningkat secara signifikan. Dalam standard Singapura, api dan polusiasap kerap terjadi dan bisa menakutkan para turis dan mengacaukan sitem transportasi mereka.

Kabut asap akibat kebakaran hutan di Indonesia yang mulai mencemari udara Singapura, tampaknya disebabkan oleh kebakaran hutan secara liar di perkebunan-perkebunan sawit di dumai dan bengkalis, provinsi riau. Menteri sumber daya alam dan lingkungan Malaysia, Douglas Unggah Embas, juga telah menyurati Indonesia agar mengambil langkah yang pantas untuk memitigasi masalah tersebut. Namun kebakaran hutan kembali lagi terjadi kurang dari seminggu setelah para menteri lingkungan hidup asia tenggara bertemu di brunei untuk membahas masalah kebakaran hutan.$^{36}$

36 Yulie Monaliza, Prinsip PertanggungjawabanNegara Terhadap Pencemaran Udara Lintas Batas Akibat Kebakaran Hutan Indonesia Menurut ASEAN Agreement On Transboundary Haze Pollution, Skripsi, Fakultas Hukum Universitas Negeri Semarang, 2016, hlm. 64

Suloh: Jurnal Fakultas Hukum Universitas Malikussaleh, Vol. 7, No. 2, April 2019, pp. 48-76 
Pada tahun 2013, perdana Menteri Singapura, Lee Hsien Long, telah menyurati Presiden Susilo Bambang Yudhoyono, untuk menawarkan bantuan mengenai kebakaran hutan yang terjadi di wilayah Sumatra. Suratuntuk presiden tersebut berisikan tentang kekhawatiran Singapura terhadap kabut asap akibat kebakaran hutan di Indonesia, dan menawarkan kepada pemerintah Indonesia. Singapura telah mengirim CEO bdan Lingkungan Hidup Nasional Singapura, Andrew Tan, ke Indonesia untuk bertemu dengan pejabat terkait di Indonesia untuk memintai pertanggungjawaban kepada Pemerintah Indonesia.

Tanggungjawab negara dibidang lingkungan berdasarkan perjanjian Internasional seperti dikatakan oleh Hamzah. Dalam Hukum Internasional, ketentuan berkenaan dengan masalah pertanggungjawaban negara ini memang belum ada yang pasti. International Law Commision (ILC), salah satu organ PBB yang bertugas untuk melakukan perumusan dan pembahasan ketentuan dan hukum internasional sampai saat ini masih berusaha merumuskan dan membahas Drafttentang ketentuan tanggungjawab negara.

Meskipun kerjanya masih dalam bentuk draft, tetapi aktivitas ILC dalam mempersiapkan dan melakukan perkembangan hukum Internasional khususnya mengenai tanggungjawab negara yang dilakukan oleh para ahli hukum terkemuka yang mewakili kebudayaan-kebudayaan terpenting di dunia yang mempunyai nilai tinggi yang tergabung di dalam panitia Hukum Internasional (ILC), dapat digunakan sebagai sumber tambahan hukum Internasional. jika ketentuan ini dipakai dalam praktik kenegaraan maka akan menjadi Hukum Kebiasaan Internasional.

Dalam konteks perlindungan, untuk mengetahui ada tidaknya pertanggungjawaban negara (responsibility) dan atau (liability) dalam suatu peristiwa, Zamanek mengingatkan perlunya dilakukan penelitian terhadap empat aspek dari keadaan faktual yang bersangkutan, yang meliputi: akibat (effect); kegiatan (aktivity); tempa/ruang lingkup (space); serta sumber dan korban (sources and victims). Mengenai ada tidaknya akibat yang ditimbulkan dala suatu peristiwa, pertama-tama perlu untuk dibedakan mengenai pengertian kerusakan (damage) dan pengertian membahayakan (harm). ${ }^{37}$ Dalam Hukum Internasional, yaitu sebagaimana dirumuskan dalam Liability Treaty-1972, pengertian "kerusakan" didefisnisikan sebagai: "The term 'damage' means loss of life, personal injury or other impainrment of health, or loss of or damage to property of States or persons, natural or juridicial, or property of international intergovermental organization (istilah 'kerusakan' berarti hilangnya nyawa, cedera atau gangguan lain dari kesehatan, atau kehilangan atau kerusakan harta benda negara atau orang, atau badan hukum, atau milik organisasi antar pemerintahan internasional)".

Deklarasi Universal Hak-hak Asasi Manusia Pasal 25 juga memberikan pernyataan bahwa:

1. Everyone has the right to a standard of living adequate for the health and well being of himself and of his family, including food, clothing housing and

37 Ibid., hlm 56

Suloh: Jurnal Fakultas Hukum Universitas Malikussaleh, Vol. 7, No. 2, April 2019, pp. 48-76 
medical care and necessary social services, and the right to security in the event of unemployment beyond his control. ("setiap orang berhak atas taraf hidup yang menjamin kesehatan dan kesejahteraan dirinya dan keluarganya, termasuk pangan, pakaian, perumahan dan perawatan kesehatan serta pelayanan sosial yang diperlukan, dan berhak atas jaminan pada saat menganggur, sakit, cacat, janda, lanjut usia atau kurangnya mata pencaharian yang lain di luar kekuasaanya").

2. Motherhood and childhood are entitled to special care and assistance. All children, whether born in or out of wedlock, shall enjoy the same social protection ("ibu dan anak berhak atas perawatan dan bantuan khusus. Semua anak, baik yang lahir dalam atau di luar nikah, harus menikmati perlindungan sisial yang sama").

Ketentuan Pasal 1 Draft International Law Commision (ILC) tentang pertanggungjawaban negara berisi bahwa: setiap negara yang melakukan suatu tindakan yang merugikan Hukum Internasional akan mengakibatkan tanggung jawab pada suatu negara tersebut". Selain itu sesuai dengan prinsip ke-14 Deklarasi Rio 1991 yang mengatakan "Pencegahan peralihan bahan peusak lingkungan dari satu negara ke negara lainnya oleh setiap pemerintah".

Pada Bab X Pasal 65 butir 1 Undang-Undang Nomor 32 Tahun 2009 tentang Perlindungan dan Pengelolaan Lingkungan Hidup menyebutkan bahwa "setiap orang berhak atas lingkungan yang baik dan sehat sebagai bagian dari "hak asasi manusia". Demikian pula Deklarasi Universal PBB mengenai HakHak Asasi Manusia 10 Desember 1948 menegaskan bahwa setiap orang berhak atas standar kehidupan yang memadai untuk kesehatan dan kesejahteraan dirinya. ${ }^{38}$

Tanggung jawab negara terhadap akibat-akibat dari tindakannya terhadap negara lain dan hak-hak negara terhadap lingkungan ditegaskan pula dalam Konferensi PBB tentang Lingkungan Hidup di Stockhlom tahun 1972. Prinsip 21 Deklarasi Stockholm (Resolusi MU No. 2992 (XXVII) 15 Desember 1972) menyatakan bahwa setiap negara mempunyai hak berdaulat untuk mengekploitasi kekayaan alamnya dan bertanggungjawab agar kegiatan ekploitasi yang dilakukan di dalam wilayah atau di bawah pengawasannya tersebut tidak menyebabkan kerugian terhadap negara lain. Rumusan yang sama ditetapkan dalam Pasal 194 Konvensi Hukum Laut 1982 yitu: "bahwa negara harus mengambil tindalan yang perlu untuk menjamin agar kegiatan-kegiatan yang berada di bawah yurisdiksinya atau di bawah pengawasannya dilakukan dengan cara sedemikian rupa sehingga tidak mencemari wilayah negara lain. ${ }^{39}$

Dalam Draft Articles on State Responsibility yang diadopsi oleh Komisi Hukum Internasional (ILC), disebutkan dalam pasal 1 bahwa "Every internationally wrongful act of a State entails the international responsibility of that State". Jadi setiap tindakan atau kelalaian yang dilarang oleh Hukum Internasional membawakan pertanggungjawaban tnternasional bagi negara itu.

\footnotetext{
38 The Universal Declaration Of Human Right, 2000

39 Yulia Monaliza., Op.cit, hlm 56.
} 
Draft ILC tersebut tidak mengikat sebagai suatu instrumen Hukum Internasional karena belum ditetapkan sebagai sebuah produk hukum. Namun demikian, kekuatan mengikat Draft ILC tidak dilihat dari bentuknya sebagai suatu intrumen, melainkan dari isinya. Draft ILC dapat digunakan sebagai sumber tambahan dan mengikat sebagai Hukum Kebiasaan Internasional. ${ }^{40}$

Dalam Draft ILC didapat pengertian bahwa Draft ketika dilihat dari bentuknya bahwa Draft ILC tersebut tidak mengikat namun isi dari Draft ILC tersebut dapat dijadikan sebagai sumber hukum tambahan yang mengikat untuk menerapkan suatu pertanggungjawaban negara. Ini berarti pertanggungjawaban yang sudah di uraikan diatas sudah memenuhi Hukum Kebiasan Internasional atau diartikan Indonesia melakukan pertanggungjawaban mengikuti Kebiasaan Hukum Internasional yang ada.

Indonesia merupakan negara yang setiap tahunnya mengalami permasalahan lingkungan hidup yang dampaknya sampai ke negara tetangga, untuk itu Indonesia menanggapi permasalahan lingkungan internasional ini dengan mulai mengadopsi konsep pertanggungjawaban negara (state responsibility). Dengan mengadopsi konsep tersebut dapat menunjukkan menjadi bentuk pertanggungjawaban negara terhadap pencemaran yang mengakibatkan injury bagi negara lain.

Berdasarkan Konferensi Lingkungan Hidup Internasional yang memuat tentang state responsibility ini terdapat dalam Pasal 21 Deklarasi Stockholm 1972, sebagai berikut: "State have, in accordance with the Charter of the United Nations and the principles of internastional law, the sovereign right to exploit their own resources pursuant to their own environmental policies, and the responsibility to ensure that activities within their jurisdiction or control do not cause damage to the environment of other States or of areas beyond the limits of national jurisdiction" (Suatu negara, sesuai dengan Piagam Bangsa Bangsa dan prinsip-prinsip hukum internasional, suatu hak berdaulat untuk mengeksploitasi sumber daya mereka sendiri sesuai dengan peraturan lingkungan negara itu sendiri, dan tanggung jawab untuk memastikan bahwa aktifitas dalam yurisdiksi atau pengawasan mereka tidak menyebabkan kerusakan lingkungan negara lain atau kawasan diluar batas yuridiksi nasional).

Pada awalnya prinsip tanggung jawab negara berada dalam pelaksanaan secara internal, yaitu sejauh mana suatu entitas negara melakukan suatu kegagalan dalam memberikan fungsi kedamaian dan kesejahteraan yang layak bagi warganya. Prinsip tanggung jawab negara juga mempunyai fungsi eksternal, serta mempunyai fungsi internal, yaitu terhadap warga negara dari yang bersangkutan. Perbedaan signifikan dari bentuk pertanggungjawaban negara terhadap warga negara adalah objek dari penerapan prinsip ini yaitu melibatkan hubungan antara negara atau pemerintah yang melaksanakan fungsi negara dari negara yang bersangkutan.

Suatu prinsip pertanggungjawaban negara sebagai salah satu prinsip utama dalam hukum internasional pada intinya memuat kewajiban negara yang

40 Ibid., hlm. 57

Suloh: Jurnal Fakultas Hukum Universitas Malikussaleh, Vol. 7, No. 2, April 2019, pp. 48-76 
memberikan dampak kepada negara lain untuk melakukan suatu reparasi kepada negara yang dirugikan dan mengembalikan kondisi negara yang bersangkutan seperti semula. Keberadaan hukum lingkungan internasional sebagai salah satu cabang dari hukum internasional turut pula membawa pemberlakuan dari prinsip pertanggungjawaban negara dalam beberapa kasus hukum lingkungan internasional seperti yang dapat ditemui dalam Trial Smelter Case 1938 yang melibatkan dengan Kanada, Corfu Channel Case 1949 antara Inggris dan Albania, dan Lake Lanoux Case 1957 antara Perancis dan Spanyol.

Seiring dalam perkembangan perspektif masyarakat internasional yang menganggap bahwa lingkungan hidup adalah suatu kesatuan internasional (wholeness) tanpa adanya batas administratif, keberadaan prinsip pertanggungjawaban negara mulai tergeser dengan prinsip Common But Differentiated Responsibility yang menekankan pada tanggung jawab secara bersamasama yang didasari oleh suatu pertanggungjawaban hukum oleh negara tertentu.

\section{A. Penyelesaian Sengketa Hukum Internasional Terhadap Kebakaran Hutan di Indonesia}

Aktivitas negara dalam menjalankan hubungan internasional kadangkala tidak dapat terhindar dengan resiko timbulnya konflik dan kesalahan. Sehingga dibutuhkan suatu konsep dimana, ketika negara tersebut melakukan kesalahan, negara tersebut berkewajiban memulihkan atau memperbaiki kesalahannya. Dewasa ini, konsep pertanggungjawaban negara terus mengalami perkembangan sesuai dengan perkembangan jaman. Para ahli hukum internasional mengakui bahwa tanggung jawab negara merupakan suatu prinsip fundamental hukum internasional. ${ }^{41}$

Prinsip tanggung jawab negara lahir dari kewajiban internasional yang bersifat primer (primary rules of obligation), yakni suatu prinsip keseimbangan antara hak dan kewajiban suatu negara. Setiap negara yang menyandang hak tertentu adalah juga merupakan subjek yang mendukung kewajiban tertentu pula. Kewajiban ini merupakan sisi lain dari hak yang diberikan oleh hukum. ${ }^{42}$

Fungsi dasar dari prinsip tanggung jawab negara dalam kajian hukum internasional adalah untuk memberikan perlindungan kepada setiap negara, antara lain dengan cara mewajibkan setiap negara pelanggar membayar ganti rugi kepada negara yang menderita kerugian yang diakibatkannya. Pertanggungjawaban negara biasanya dilakukan dalam bentuk perbaikan, rehabilitasi ataupun ganti rugi, dan bentuk pertanggungjawabannya sangat tergantung pada peristiwa yang terjadi.

\footnotetext{
${ }^{41}$ M.N. Shaw, International Law, edisi 2, Butterworths, London, 1986, hlm. 466, dalam Ian Brownlie, 1979 Principles of Public International Law, Oxford University Press,hlm. 431, seperti dikutip oleh Huala Adolf, Aspek-Aspek Negara dalam Hukum Internasional, PT Radja Grafindo Persada, Jakarta, 1996, hlm. 174

${ }^{42}$ Arif, , Pencemaran Transnasional Akibat Kebakaran Hutan di Indonesia dalam ubungannya dengan Penerapan Prinsip Tanggung Jawab Negara, Tesis Pasca Sarjana Universitas Padjajaran, Bandung, 2000, hlm. 47
}

Suloh: Jurnal Fakultas Hukum Universitas Malikussaleh, Vol. 7, No. 2, April 2019, pp. 48-76 
Dalam praktiknya, negara yang menderita kerugian akan meminta sesuatu yang bersifat satisfaction melalui cara-cara diplomatis. Disisi lain, apabila suatu negara merasa kehormatannya direndahkan, permohonan maaf resmi dari negara yang melakukan perbuatan tersebut merupakan bentuk tanggung jawab negara yang akan dilakukan. Sedangkan kesalahan negara yang menimbulkan suatu kondisi kerugian dan membutuhkan perbaikan ataupun kompensasi, jalur hukum biasanya akan diajukan kepada badan arbitrase internasional atau tribunal untuk memutuskan suatu perkara.

Dalam konteks kerusakan lingkungan, pelaksanaan kegiatan di dalam suatu wilayah negara terhadap lingkungannya merupakan perwujudan kedaulatan dari suatu negara. Jika kegiatan tersebut menimbulkan kerugian bagi negara lainnya (the act injuries to another states) maka timbullah tanggung jawab negara. Prinsip responsibility dikaitkan pula dengan legal strategy, yakni upaya pencegahan terhadap suatu aktivitas dengan cara menetapkan standar permisible injury atau ambang batas dari kerusakan lingkungan. Kerusakan lingkungan (environmental injuries) dapat pula dianggap sebagai ongkos eksternal yang timbul dari kegiatan ekonomi. Adanya kerusakan lingkungan ditetapkan berdasarkan ambang batas atau baku mutu lingkungan.

Penetapan permisible injury dilakukan berdasarkan putusan pengadilan internasional, atau penetapan standar perbuatan yang dapat menimbulkan kerusakan lingkungan, dan melalui pelaksanaan fungsi pengaturan oleh badanbadan internasional. Sebagian besar tanggung jawab negara ini didasarkan pada ketentuan larangan injury of one state to another. Berbeda halnya apabila suatu kerusakan tersebut terjadi di wilayah yang termasuk common heritage of mankind (wilayah-wilayah yang merupakan warisan bersama umat manusia) maka tanggung jawab yang timbul adalah tanggung jawab internasional (shared responsibility). Dalam kajian hukum lingkungan internasional, terdapat beberapa prinsip yang diakui dan diatur secara internasional. Salah satu prinsipnya principles of good neighbourliness yang mengatur kewajiban Negara untuk tidak menganggu kedaulatan Negara lain. Prinsip selanjutnya yakni preservation and the protection of environment yang menegaskan tindakan-tindakan apa saja yang perlu diambil untuk mencegah dampak buruk kerusakan lingkungan bagi kondisi yang baik di masa depan. Kemudian preventive principle yang mengatur terkait upaya-upaya pencegahan kerusakan lingkungan.

Pelanggaraan terhadap prinsip-prinsip diatas akan berimbas kepada penerapan prinsip berikutnya yakni prinsip ke 21 Deklarasi Stockholm yang menuntut negara pencemar untuk melakukan usaha perbaikan akibat perbuatannya. Pendekatan yang sama ini bisa juga dilihat dalam Pasal 2 (1) dari Konvensi ECE tentang Pengendalian Dampak Lingkungan yang menyatakan setiap negara harus ikut serta dalam upaya pencegahan dan mengurangi dampak pencemaran lintas batas. Pada umumnya kewajiban setiap negara adalah mewujudkan langkah-langkah administratif dan legislatif untuk melindungi lingkungan sehingga dapat dikatakan sebagai pemerintah yang baik. Menurut starke, sengketa-sengketa internasional bukan saja mengenai sengketa antara negara-negara, melainkan juga kasus-kasus lain yang berada dalam lingkup 
pengaturan internasional yakni beberapa kategori sengketa terntentu antara negara di satu pihak dan individu-individu, badan-badan korporasi serta badan-badan bukan negara di pihak lain.

Menurut stani, penyelesaian sengketa secara damai dibedakan menjadi penyelesaian melalui pengadilan dan penyelesaian di luar pengadilan. Penyelesaian melalui pengadilan yaitu dapat berupa: ${ }^{43}$

\section{Penyelesaian Melalui Pengadilan}

\section{a. Penyelesaian Melalui Arbitrase Internasional}

Arbitrase adalah suatu cara penyelesaian sengketa di luar pengadilan dengan cara menyajikan sengketa kepada orang-orang tertentu, yang dipilih secara bebas oleh pihak-pihak yang bersengketa untuk memutuskan sengketa itu tanpa harus memperhatikan hukum secara ketat. Hakikat arbitrase adalah prosedur penyelesaian sengketa konsensual dalam arti bahwa penyelesaian hanya akan dicapai bila kedua negara (pihak-pihak) yang bersengketa melakukan persetujuan. Hal-hal yang perlu ditekankan pada arbitrase adalah perlunya persetujuan pada pihak dalam setiap tahapan arbitrase, dan persengketaan itu harus diselesaikan dengan selalu menghormati hukum internasional.

Dalam lembaga arbitrase terdiri atas: seorang arbitor, komisi bersama anatara anggota-anggota yang ditunjuk oleh para pihak yang bersengketa, formasi campuran yang terdiri dari orang-orang yang diajukan oleh pihak yang bersengketa dan anggota tambahan yang dipilih dengan cara lain. Pengadilan arbitrasi ini dilaksanakan oleh suatu panel hakim atau arbitrator yang dibentuk atas dasar persetujuan khusus para pihak, atau dengan perjanjian arbitrasi yang telah ada. ${ }^{44}$

\section{b. Pengadilan internasional}

Pengadilan internasional yang dapat digunakan sebagai sarana penyelesaian sengketa internasional adalah Mahkamah Internasional (International Court ofJustice). Mahkamah ini dapat dimanfaatkan oleh negara manapun di dunia, karena Mahkamah ini terbuka bagi:

1) Nagara-negara baik anggota atau bukan anggota PBB,

2) Negara-negara lain dengan syarat-syarat yang ditentukan oleh dewan keamanan PBB, dan tuntuk pada ketentuan-ketentuan khusus yang dimuat dalam traktat yang berlaku.

Dalam praktik, masyarakat internasional (negara-negara) relatifjarang memakai Mahkamah Internasional untuk menyelesaikan sengketa. Hal ini anatara lain disebabkan oleh:

1) Proses penyelesaian di mahkamah internasional hanya ditempuh sebagai jalan terakhir.

2) Waktu penyelesaian sengketa relatif lama.

3) Biaya perkara besar.

\footnotetext{
43 Widodo, Hukum Internasional Publik, Aswaja Pressindo, Yogyakarta, 2017, hlm. 189

44 Ibid., hlm 190
} 
4) Kasus yangdiajukan harus merupakan persengketaan internasional yang besar.

5) Mahkamah internasional tidak mempunyai yuridiksi wajib.

Mahkamah internasional mempunyai beberapa karakteristik yang unik dan tidak dimiliki oleh lembaga peradilan lain. Karateristik tersebut adalah sebagaimana terjabar pada uraian berikut. ${ }^{45}$

1) Pihak yang boleh berperkara (menuntut) dalam Mahkamah Internasional hanyalah negara, tetapi individu justru dapat dituntut melalui pengadilan ini.

2) Pada prinsipnya suatu negara boleh mengajukan sengketa secara sepihak ke Mahkamah Internasonal, tetapi negara lawan sengketa harus menyetujui bahwa kasusnya akan diselesaikan melalui Mahkamah Internasional.

Menurut Tsani, ${ }^{46}$ penyelesaian diluar pengadilan dapat ditempuh dengan jalan: negosisasi, mediasi, good offices (jasa baik), konsialiasi, inquiry (penyelidikan), fact finding (penemuan fakta), penyelesaian regional, dan penyelesaian dibawah PBB.

\section{Penyelesaian di luar Pengadilan}

\section{a. Negosiasi}

Untuk menyelesaikan persengketaan anta-negara melalui negosiasi ini ternyata peranan diplomasi sutau negara sangat menentukan. Karena pada hakikatnya negosiasi adalah pertukaran pendapat dan usulan anatara para pihak yang bersengketa untuk mencari alternatif penyelesaian sengketa secara damai. Negosiasi ini biasanya dipakai sebagai metode awal sebelum metode/teknik lain digunakan, tetapi apabila melalui metode negosiasi ini persengketaan sudah dapat diselesaikan maka metode lainnya tidak perlu digunakan.dalam metode negosiasi ini peran serta negara lain diluar pihak yang bersengketa tidak diperlukan. ${ }^{47}$

Dalam negosiasi, para wakil (mungkin kepala negara, perdana menteri, menteri luar negeri, pejabat departemen, pejabat khusus yang dibentuk, pimpinan partai atau pimpinan-pimpinan lembaga kemasyarakatan) akan mengajukan usul, alasan, pendapat, berdasarkan kepentingan nasionalmya masing-masing untuk selanjutnya dicarikan jalan pemecahannya (solusi) yang terbaik dan dapat diterima oleh kedua belah pihak.

Pelaksanaan negosiasi tidak harus dilakukan secara resmi, tetapi dapat juga dilaksanakan secara informal, misalnya pada sela-sela jamuan makan, pada forum khusus yang bersifat informal atau bahkan dapat juga dilakukan di koridor-koridor hotel yang kondusif dan sopan. Dalam kaitannya dengan negosisasi informal, Merrils menjelaskan bahwa negosiasi informal telah banyak membawa kearah suksesnya penyelesaian, menolong tercapainya penyelesaian sengketa yang tidak bisa dicapai dalam diskusi resmi. Secara umum baik

\footnotetext{
45 Ibid., hlm. 191

46 Ibid., hlm 193

47 Ibid., hlm. 196
}

Suloh: Jurnal Fakultas Hukum Universitas Malikussaleh, Vol. 7, No. 2, April 2019, pp. 48-76 
negosiasi formal maupun informal dapat dilakukan secara bilateral maupun multilateral dan atas maslaah appun juga. ${ }^{48}$

\section{b. Mediasi}

Mediasi adalah penyelesaian sengketa antara negara secara damai dengan jalan turut melibatkan pihak ke tiga (baik individu maupun negara) ke dalam negosiasi sebagai upaya mencapai kesepakatan. Peran mediator menurut konvensi Den Haag tahun 1899 adalah mendamaikan tuntutan yang saling berlawanan serta meredakan rasa dendam yang mungkin timbul di antara negara yang bertengkar/ berkonflik. Walau demikian saran mediator tidak mempunyai dasar ikat yang kuat terhadap negara yang bersengketa.

Contoh mediasi yang ada adalah terselesaikannya sengketa Distrik Mindanau Selatan di Philipina. Pada saat itu Menteri Luar Negeri Ali Alatas (Indonesia) bersama Organisasi Kerjasama Islam (OKI) menjadi mediator dalam perundingan kasus Mindanau Selatan antara Fidel Ramos (Presiden Philipina) dengan NurMisywari (Pemimpin Distrik Mindanau Selatan yang sebagian besar penduduknya beragama islam). Alhasil mediasi itu mengalami proses yang lancar sehingga sengketapun dapat diselesaikan. ${ }^{49}$

Namun jika dilihat dari subtansinya, kebakaran hutan di Indonesia belum belum dikategorikan sebagai sengketa internasional, karena jika dilihat dari kasus kebakaran hutan yang terjadi di Indonesia belum ada negara yang mengajukan klaim atas yuridiksinya melaikan hanya sebatas protes di negara-negara yang berdampak akibat kebakaranhutan di Indonesia.

Protes, atau dapat didefinisikan sebagai komunikasi formal dari suatu subyek internasional kepada subyek internasional lainnya untuk mengutarakan keberatan terhadap pelanggaran hukum internasional, ${ }^{50}$ Negara yang sering terkena dampak akibat kebakaran hutan di Indonesia seperti Malaysia dan Singapura belum mengajukan secara resmi lewat jalur yuridis namun paksaan dengan jalur diplomatik dari kedua negara tersebut kepada Indonesia sudah cukup besar untuk mengatasi masalah ini. Cara penyelesaian sengketa yang paling tradisional adalah dengan perundingan secara langsung (negotiation). Perundingan diadakan dalam bentuk-bentuk pembicaraan langsung antara negaranegara yang bersengketa dalam pertemuan tertutup antara wakil-wakilnya. Perundingan-perundingan langsung ini biasanya dilakukan menteri-menteri luar negeri, duta-duta besar atau wakil-wakil yang ditugaskan khusus untuk berunding dalam kerangka diplomasi ad hoc. Ada kalanya sengketa itu juga di internasionalisasikan dalam sebuah konferensi internasional. ${ }^{19}$

Dalam kasus kebakaran hutan di Indonesia cara yang paling tepat dalam penyelesaian sengketa internasional yaitu dengan Negosiasi, dalam menyusun draft-draft kesepakatan dalam menyelesaikan masalah kebakaran hutan. Konferensi internasional juga terbukti dengan adanya Sub Regional Ministerial Meeting dalam lingkup ASEAN.

48 Ibid., hlm 197

49 Ibid., Hlm. 198

50 Boer Mauna, Hukum Internasional: Pengertian, Peranan dan Fungsi dalam Era Dinamika Global, Bandung, Alumni, 2000 hlm. 190

Suloh: Jurnal Fakultas Hukum Universitas Malikussaleh, Vol. 7, No. 2, April 2019, pp. 48-76 


\section{Kesimpulan}

Dari uraian-uraian yang telah dijabarkan pada bab-bab sebelumnya, mak dapat ditarik kesimpulan sebagai berikut:

1. Pertanggungjawaban negara terhadap kebakaran hutan di Indonesia telah di atur dalam berbagai peratutan perundang-undangan, juga jika dilihat dari perspektif hukum internasional, dalam Draft Articles on State Responsibility yang di adopsi oleh Internationl Law Commision. Tanggungjawab negara diatur dalam pasal-pasal Draft Articles on State Responsibility. Adapun Ganti rugi atau reparation diatur dalam pasal 31 yaitu berupa : (1) restitution (pasal 35): kewajiban mengembaikan keadaan yang dirugikan seperti semula. (2) compesation (pasal 36): Kewajiban ganti rugi berupa materi atau uang. (3) satification (pasal 37): permintaan maaf. Pertanggungjawaban Negara Indonesia terhadap kebakaran hutan dilakukan dalam bentuk permintaan maaf kepada negara-negara terdampak pencemaran asap akibat kebakaran hutan dan upaya penangan secraa maksimal tetap dilakukan oleh negara Indonesia. Pada pasal 5 angka 1 Agreement on Transboundary Haze Pollution disebutkan bahwa ASEAN membentuk pusat koordinasi ASEAN untuk pengendalian penecemaran udara yang diakibatkan oleh kebakaran hutan yang selanjutnya disebut ASEAN Centre, dengan ini didirikan untuk tujuan memfasilitasi kerjasama dan koordinasi antar para pihak dalma mengelola dampak dari kebakaran hutan khususnya pencemaran asap yang ditimbulkan dari kebakaran tersebut. Pasal tersebut menimbulkan hak bagi negara-negara yang terkena dampak kebakaran hutan yang akan ditindak lanjuti leh ASEAN Centre.

2. Secara hukum internasional, penyelesaian sengketa terhadap kebakaran hutan di Indonesia dapat diselesaikan dengan beberapa cara yakni penyelesaian melalui pengadilan dan penyelesaian diluar pengadilan, penyelesaian melalui pengadilan berupa Arbitrase Internasional yaitu suatu penyelesaian sengketa yang dilakukan dengan cara menyajikan sengketa kepada aorang-orang tertentu dan sengketa tersebut harus persetujuan kedua belah pihak yang bersengketa, kemudian penyelesaian sengketa melalui pengadilan internasional (Mahkamah Internasional) mahkamah internasional ini berfungsi mengadili setiap negara-negara baik anggota atau bukan anggota PBB yang bersengketa. Kemudian ada juga penyelesaian diluar pengadilan yang berupa negosisasi, mediasi, jasa baik, konsiliasi, penyelidikan, penemuan, dan penyelesaian regional.

\section{DAFTAR PUSTAKA}

\section{A. Buku}

Andi Hamzah, Kamus Hukum, (Jakarta: Ghalia Indonesia, 1986).

Andreas Pramudianto, Hukum Perjanjian Lingkungan Internasional, cet. Pertama, (Malang: Setara Press, 2014)

A.Z Nasution, Hukum Perlindungan Konsumen (suatu pengantar), Edisi Revisi, (Jakarta: Diadit Media, 2011). 
Boer Mauna. Hukum Internasional Pengertian, Peranan dan Fungsi dalam Era Dinamika Global.(Bandung : PT Alumni, 2005).

C.S.T. Kansil \& Christine S.T. Kansil, Pengantar Ilmu Hukum Indonesia, (Jakarta: Rineka Cipta, 2011).

David J. Harris, Cases and Materials on International Law, (London: Sweet and Maxwell, 1982).

Frans Magnis Suseno, Etika Politik Prinsip-Prinsip Moral Dasar Kenegaraan Modern, (Jakarta: PT. Gramedia Pustaka Utama, 2001).

H Salim HS, Erlies Septiana Nurbani, Penerapan Teori Hukum, (Penelitian Tesis Dan Disertasi, Jakarta 2014).

I Wayan Parthiana, Hukum Perjanjian Internasional, cet.1, (Bandung: Mandar Maju, 2018)

Joseph P Harris-Consulting editor, Introduction to the law of nation, McGraw Hill Series Ins., Politcal Science, (New York-Toronto-London.1935).

J.G. Starke, Pengantar Hukum Internasional 2, edisi kesepuluh, (Sinar Grafika)

Koesnadi Hardjasoemantri, Hukum Tata Lingkungan, edisi VIII, (Gadjah Mada University Press, Yogyakarta, 2005).

Malcolm N. Shaw, International Law, (Cambridge: Cambridge University Press, 1997)

Mochtar Kusumaatmaja. Pengantar Hukum Internasional. (Rosda Offset, Bandung.1981).

Muhammad Akib, Hukum Lingkungan Perspektif Global dan Nasional, edisi revisi, (PT RajaGrafindo Persada, Jakarta, 2014).

Muhammad Daud Silalahi, Hukum Lingkungan Dalam Sistem Penegakan Hukum Lingkungan Indonesia, edisi revisi, (Bandung: PT Alumni, 2001).

Muhammad Solly Lubis, Filsafat Hukum dan Penelitian, (Bandung: Mandar Maju, 1994)

Peter Mahmud Marzuki, Penelitian Hukum: Edisi Revisi, Cet. 8, Kencana Prenada Media Group, Jakarta, 2013

Samidjo, Ilmu Negara, (Bandung: Armico, 1986).

Sedarmayanti dan Syarifudin Hidayat, Metodologi Penelitian, (Bandung: Mandar Maju, 2002).

Soehino, Ilmu Negara, (Yogyakarta: Penerbit Liberty, 2000).

Soekanto, Soejono, Pengantar Meode Penelitian, Jakarta: UI Press, 1986.

Sugeng Istanto. Hukum Internasional. (Yogyakarta: Penerbitan Universitas Atma Jaya Yogyakarta, 1998).

------ ,dan Sri Mamuji, Penelitian Hukum Normatif Sutu Tinjauan singkat, (Jakarta: RajaGrafindo Persada, 2010)

Takdir Rahmadi, Hukum Lingkungan di Indonesia, cet. 2, (Jakarta: Rajawali Press, 2015)

Widodo, Hukum Internasional Publik, cet. 1 (yogyakarta: Aswaja Pressindo, 2017)

Y. Sri Pudyatmoko, Perizinan :Problem dan Upaya Pembenahan, (Jakarta, PT. Gramedia Widiasarana Indonesia, 2009). 


\section{B. Peraturan Perundang-Undangan}

Undang-Undang Dasar Negara republik Indonesia Tahun 1945.

Undang-Undang Nomor 411999 tentang Kehutanan

Undang-Undang Nomor 32 Tahun 2009 tentang Perlindungan dan Pengelolaan Lingkungan Hidup.

Undang-undang nomor 38 Tahun 2008 Tentang Pengesahan Charter of The Association of Southeast Asian Nations (Piagam Perhimpun Bangsa-Bangsa Asia Tenggara)

Undang-Undang Nomor 26 Tahun 2014 tentang Pengesahan ASEAN Agreement on Transboundary Haze Pollution (Persetujuan ASEAN tentang Pencemaran Asap Lintas Batas.

\section{Tesis/Jurnal/Skripsi/Makalah/Artikel/Majalah/Koran}

Arif, Pencemaran Transnasional Akibat Kebakaran Hutan Di Indonesia Dalam Hubungannya Dengan Penerapan Prinsip Tanggung Jawab Negara, Jurnal Hukum 2000.

Dina Manarung, Pengaturan Hukum Internasional tentang Tanggungjawab Negara Dalam Pencemaran Udara Lintas Batas, Jurnal Hukum, 2014

Maya, Octavia. Pertanggungjawaban Indonesia Terhadap Kasus Polusi Udara Lintas Batas Dalam Perspektif AATHP. Jurnal hukum Internasional. 2007

Sari. Kajian Ekologis Atas Dampak Kebakaran Hutan yang Bersifat Lintas Batas. Jurnal hukum lingkungan. 2009.

\section{Ketentuan/ Perjanjian Internasional}

Stockhlom Declaration Human Environment (1972)

United Conference onThe Human Environment (1972)

Rio Declaration on Environmen and Development (1992)

ASEAN Agreement on Transboundary Haze Pollution (2002)

International Law Comission Yearbook. 